


\section{Report Documentation Page}

Form Approved

OMB No. 0704-0188

Public reporting burden for the collection of information is estimated to average 1 hour per response, including the time for reviewing instructions, searching existing data sources, gathering and maintaining the data needed, and completing and reviewing the collection of information. Send comments regarding this burden estimate or any other aspect of this collection of information,

including suggestions for reducing this burden, to Washington Headquarters Services, Directorate for Information Operations and Reports, 1215 Jefferson Davis Highway, Suite 1204, Arlington

VA 22202-4302. Respondents should be aware that notwithstanding any other provision of law, no person shall be subject to a penalty for failing to comply with a collection of information if it

does not display a currently valid OMB control number.

1. REPORT DATE

JUL 2015

4. TITLE AND SUBTITLE

The Limits of Military Officers' Duty to Obey Civilian Orders: A Neo-classical Perspective

6. $\operatorname{AUTHOR}(\mathrm{S})$

7. PERFORMING ORGANIZATION NAME(S) AND ADDRESS(ES)

U.S. Army War College,Strategic Studies Institute,47 Ashburn

Drive,Carlisle,PA,17013-5010

9. SPONSORING/MONITORING AGENCY NAME(S) AND ADDRESS(ES)

3. DATES COVERED

00-00-2015 to 00-00-2015

5a. CONTRACT NUMBER

5b. GRANT NUMBER

5c. PROGRAM ELEMENT NUMBER

5d. PROJECT NUMBER

5e. TASK NUMBER

5f. WORK UNIT NUMBER

8. PERFORMING ORGANIZATION

REPORT NUMBER

10. SPONSOR/MONITOR'S ACRONYM(S)

11. SPONSOR/MONITOR'S REPORT

NUMBER(S)

12. DISTRIBUTION/AVAILABILITY STATEMENT

Approved for public release; distribution unlimited

13. SUPPLEMENTARY NOTES

14. ABSTRACT

15. SUBJECT TERMS

16. SECURITY CLASSIFICATION OF:

a. REPORT

unclassified b. ABSTRACT

unclassified c. THIS PAGE

unclassified
17. LIMITATION OF ABSTRACT

Same as

Report (SAR)
18. NUMBER 19a. NAME OF

OF PAGES

73 RESPONSIBLE PERSON

Standard Form 298 (Rev. 8-98) Prescribed by ANSI Std Z39-18 


\section{The United States Army War College}

The United States Army War College educates and develops leaders for service at the strategic level while advancing knowledge in the global application of Landpower.

The purpose of the United States Army War College is to produce graduates who are skilled critical thinkers and complex problem solvers. Concurrently, it is our duty to the U.S. Army to also act as a "think factory" for commanders and civilian leaders at the strategic level worldwide and routinely engage in discourse and debate concerning the role of ground forces in achieving national security objectives.
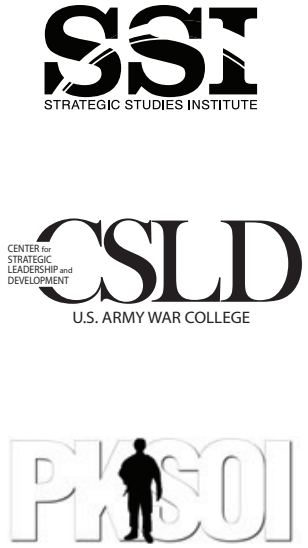

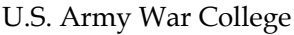

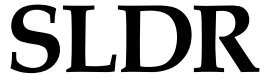

Senior Leader Development and Resiliency

The Strategic Studies Institute publishes national security and strategic research and analysis to influence policy debate and bridge the gap between military and academia.

The Center for Strategic Leadership and Development contributes to the education of world class senior leaders, develops expert knowledge, and provides solutions to strategic Army issues affecting the national security community.

The Peacekeeping and Stability Operations Institute provides subject matter expertise, technical review, and writing expertise to agencies that develop stability operations concepts and doctrines.

The Senior Leader Development and Resiliency program supports the United States Army War College's lines of effort to educate strategic leaders and provide well-being education and support by developing self-awareness through leader feedback and leader resiliency.

The School of Strategic Landpower develops strategic leaders by providing a strong foundation of wisdom grounded in mastery of the profession of arms, and by serving as a crucible for educating future leaders in the analysis, evaluation, and refinement of professional expertise in war, strategy, operations, national security, resource management, and responsible command.

The U.S. Army Heritage and Education Center acquires, conserves, and exhibits historical materials for use to support the U.S. Army, educate an international audience, and honor Soldiers-past and present. 


\section{STRATEGIC \\ STUDIES \\ INSTITUTE}

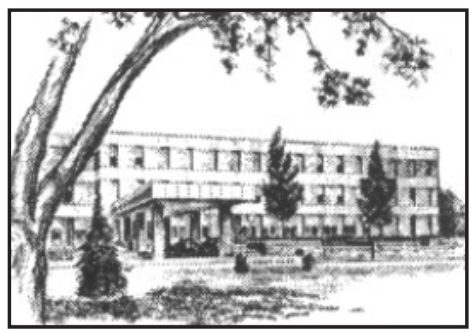

The Strategic Studies Institute (SSI) is part of the U.S. Army War College and is the strategic-level study agent for issues related to national security and military strategy with emphasis on geostrategic analysis.

The mission of SSI is to use independent analysis to conduct strategic studies that develop policy recommendations on:

- Strategy, planning, and policy for joint and combined employment of military forces;

- Regional strategic appraisals;

- The nature of land warfare;

- Matters affecting the Army's future;

- The concepts, philosophy, and theory of strategy; and,

- Other issues of importance to the leadership of the Army.

Studies produced by civilian and military analysts concern topics having strategic implications for the Army, the Department of Defense, and the larger national security community.

In addition to its studies, SSI publishes special reports on topics of special or immediate interest. These include edited proceedings of conferences and topically oriented roundtables, expanded trip reports, and quick-reaction responses to senior Army leaders.

The Institute provides a valuable analytical capability within the Army to address strategic and other issues in support of Army participation in national security policy formulation. 



\author{
Strategic Studies Institute \\ and \\ U.S. Army War College Press
}

\title{
THE LIMITS OF MILITARY OFFICERS' DUTY TO OBEY CIVILIAN ORDERS: A NEO-CLASSICAL PERSPECTIVE
}

\author{
Robert E. Atkinson, Jr.
}

July 2015

The views expressed in this report are those of the author and do not necessarily reflect the official policy or position of the Department of the Army, the Department of Defense, or the U.S. Government. Authors of Strategic Studies Institute (SSI) and U.S. Army War College (USAWC) Press publications enjoy full academic freedom, provided they do not disclose classified information, jeopardize operations security, or misrepresent official U.S. policy. Such academic freedom empowers them to offer new and sometimes controversial perspectives in the interest of furthering debate on key issues. This report is cleared for public release; distribution is unlimited.

This publication is subject to Title 17, United States Code, Sections 101 and 105. It is in the public domain and may not be copyrighted. 
Comments pertaining to this report are invited and should be forwarded to: Director, Strategic Studies Institute and U.S. Army War College Press, U.S. Army War College, 47 Ashburn Drive, Carlisle, PA 17013-5010.

All Strategic Studies Institute (SSI) and U.S. Army War College (USAWC) Press publications may be downloaded free of charge from the SSI website. Hard copies of this report may also be obtained free of charge while supplies last by placing an order on the SSI website. SSI publications may be quoted or reprinted in part or in full with permission and appropriate credit given to the U.S. Army Strategic Studies Institute and U.S. Army War College Press, U.S. Army War College, Carlisle, PA. Contact SSI by visiting our website at the following address: www.StrategicStudiesInstitute.army.mil.

$* * * * *$

The Strategic Studies Institute and U.S. Army War College Press publishes a monthly email newsletter to update the national security community on the research of our analysts, recent and forthcoming publications, and upcoming conferences sponsored by the Institute. Each newsletter also provides a strategic commentary by one of our research analysts. If you are interested in receiving this newsletter, please subscribe on the SSI website at www.StrategicStudiesInstitute.army.mil/newsletter. 
The author very much appreciates the comments and encouragement received from faculty members at the Army, Navy, and Air Force Academies and the Army and Navy War Colleges who are, quite literally, too numerous to name in the usual space. Many of them referred me to Dr. Don Snider, indisputably the dean of military professionalism studies. I can fairly say that, without his help, you would not be reading this. Nor would any of you be reading nearly so neatly annotated a version without the exceptional research assistance of Alexandra Akre, Florida State University (FSU) Law 2016, and Christopher Roberts, FSU Law 2015.

ISBN 1-58487-696-4 



\section{FOREWORD}

This monograph offers a neo-classically republican perspective on a perennial problem of civilian/military relations: limitations on military officers' obligation to obey civilian authorities. All commentators agree that military officers are generally obliged-morally, professionally, and legally - to obey civilian orders, even as they agree that this rule of obedience has exceptions. Commentators tend to differ, however, on the basis and breadth of these exceptions. Following Samuel Huntington's classic analysis in The Soldier and the State, Mr. Robert Atkinson shows that disagreement about the breadth of the exceptions tends to assume that their bases-moral, professional, and legal-are incommensurable. This monograph suggests, to the contrary, that all defensible exceptions to the rule of military obedience, like that rule itself, derive from a single neo-classical, Huntingtonian standard binding on civilian authorities and military officers alike: the common good.

This perspective promises significantly to reduce the range of disagreement over the limits of military obedience both in theory and in practice.

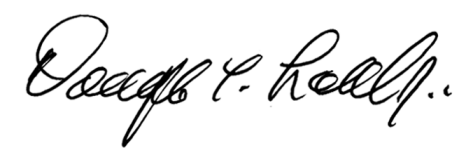

DOUGLAS C. LOVELACE, JR.

Director

Strategic Studies Institute and

U.S. Army War College Press 


\section{ABOUT THE AUTHOR}

ROBERT E. ATKINSON, JR., is the Greenspoon Marder Professor of Law, Florida State University. Previously, he clerked for Judge Donald Stuart Russell of the United States Court of Appeals for the Fourth Circuit. He practiced law with Sutherland, Asbill \& Brennan in Washington, DC, before joining the faculty at the Florida State University College of Law, where he writes and lectures on philanthropy, property, and professionalism. Mr. Atkinson holds degrees in history and philosophy from Washington and Lee University, and a law degree from Yale University. 


\section{SUMMARY}

Several post-September 11, 2001, events - the invasion of Afghanistan and the second invasion of Iraq, the use of "enhanced interrogation," the detentions at Guantanamo, the "air-only" attacks on the Islamic State in Iraq and Syria - have raised a perennially perplexing issue of civilian/military relations: principled limitations on military officers' duty to obey civilian orders. Not surprisingly, contemporary answers have split along a familiar fault line. Those on one side emphasize, more or less rigorously, officers' general professional duty to obey; those on the other emphasize, more or less expansively, familiar exceptions for irrational, illegal, or immoral orders.

Paradoxically, both sides find support in the classic statement of modern military professionalism, Samuel P. Huntington's The Soldier and the State. More paradoxically, flaws in Huntington's original analysis compound the problem, even as the correction of those flaws offers a common ground. This reexamination of Huntington's original position can thus narrow, if not wholly bridge, the gap between opponents in the current debate over military obedience.

Part I situates the general obligation of officers to obey the orders of civilian authorities in Huntington's basic theory of civilian/military relations. Part II examines two logical limitations that Huntington's theory implies for the duty of military officers to obey civilian orders: when civilian authorities usurp military officers' tactical expertise and when civilian authorities lapse in the exercise of their own expertise as "statesmen." Part III maps this latter exception onto the two general exceptions to military obedience, illegal orders and immoral orders, and then ties all 
three exceptions back into the common ground of military professionalism, the common defense, which rests on the deeper foundation of both American constitutional law and neo-classical political theory: the common good. 


\section{THE LIMITS OF MILITARY OFFICERS' DUTY TO OBEY CIVILIAN ORDERS: A NEO-CLASSICAL PERSPECTIVE ${ }^{1}$}

The aim of every political constitution is, or ought to be, first to obtain for rulers men who possess most wisdom to discern, and most virtue to pursue, the common good of society; and in the next place, to take the most effectual precautions for keeping them virtuous whilst they continue to hold the public trust.

\section{The Federalist 57 (James Madison)}

We the People of the United States, in Order to form a more perfect Union, establish Justice, insure domestic Tranquility, provide for the common defence, promote the general Welfare, and secure the Blessings of Liberty to ourselves and our Posterity, do ordain and establish this Constitution for the United States of America.

\section{Preamble, Constitution of the United States}

The professional ideology of service goes beyond serving others' choices. Rather, it claims devotion to a transcendent value which infuses its specialization with a larger and putatively higher goal which may reach beyond that of those they are supposed to serve.

Eliot Freidson, Professionalism, The Third Logic: On the Practice of Knowledge ${ }^{2}$

\section{INTRODUCTION}

Several post-September 11, 2001 (9/11) eventsthe invasion of Afghanistan and the second invasion of Iraq, the use of "enhanced interrogation," the 
detentions at Guantanamo, the "air-only" attacks on the Islamic State in Iraq and Syria (ISIS) - have raised a perennially perplexing issue of civilian/military relations: principled limitations on military officers' duty to obey civilian orders. Not surprisingly, contemporary answers have split along a familiar fault line. ${ }^{3}$ Those on one side emphasize, more or less rigorously, officers' general professional duty to obey; those on the other side emphasize, more or less expansively, familiar exceptions for irrational, illegal, or immoral orders.

Paradoxically, both sides find support in the classic statement of modern military professionalism, Samuel P. Huntington's The Soldier and the State. More paradoxically, flaws in Huntington's original analysis compound the problem, even as the correction of those flaws offers a common ground. This monograph's reexamination of Huntington's original position can thus narrow, if not wholly bridge, the gap between opponents in the current debate over military obedience.

Part I situates the general obligation of officers to obey the orders of civilian authorities in Huntington's basic theory of civilian/military relations. Part II examines two logical limitations that Huntington's theory implies for the duty of military officers to obey civilian orders: when civilian authorities usurp military officers' tactical expertise and when civilian authorities lapse in the exercise of their own expertise as "statesmen." Part III maps this latter exception onto the two general exceptions to military obedience, illegal orders and immoral orders, and then ties all three exceptions back into the common ground of military professionalism, the common defense, which rests on the deeper foundation of both American con- 
stitutional law and neo-classical political theory: the common good.

\section{PART I. HUNTINGTON'S FUNCTIONAL DERIVATION OF MILITARY DUTY AND CIVILIAN AUTHORITY}

In his 1957 classic, The Soldier and the State, Huntington proposed to solve the classical dilemma of civilian/military relations: having a military strong enough to protect the political community without making that military a threat to the political community. Huntington's solution was what he called "objective civilian control," in which "[a] highly professionalized officer corps stands ready to carry out the wishes of any civilian group which secures legitimate authority within the state." ${ }^{4}$ That would give the perfect balance of maximum military preparedness and minimum risk of military insubordination. ${ }^{5}$ Military professionalism, in that arrangement, entails two basic components, one intellectual and the other moral: ${ }^{6}$ the competence needed to defend the homeland, the military's functional imperative, ${ }^{7}$ and the virtue necessary to prevent abuse of that competence at the expense of civilian values, the military's societal imperative. ${ }^{8}$

In Huntington's first-best, ideal solution to the problem of military/civilian relations, a professionalized military high command is perfectly matched to a professionalized upper echelon of civil servants, whom he calls "statesmen." The relative scopes of their respective expertises are the basis for their entire relationship, with each deferring to the other in their particular fields: 
The military profession is expert and limited. Its members have special competence within their field and lack that competence outside their field. The relationship of the profession to the state is based upon this natural division of labor. The essence of this relationship concerns the relative scope of competence of the military expert and political expert or statesman. ${ }^{9}$

As Huntington elaborates on this relationship, two critical elements become clear. First, each has its proper sphere; second, each must be a proper expert within its sphere. The military officer, as a professional, is an expert about one means of achieving state ends, the management of violence; "it is this area within which the statesman must accept the judgment of the military professional."10

Statesmen, by contrast, use military means toward state ends. This is their domain, and in this domain lies their own corresponding competence:

Politics deals with the goals of state policy. Competence in this field consists in having a broad awareness of the elements and interests entering into a decision and in possessing the legitimate authority to make such a decision. Politics is beyond the scope of military competence. ... ${ }^{11}$

Statesmen, in Huntington's model, are experts with special competence in the ends of state action; military officers are experts with special competence is one particular means of achieving state ends, organized violence. Logically, then, military officers must be subordinate to statesmen, as means are subordinate to ends. 
The criteria of military efficiency are limited, concrete, and relatively objective; the criteria of political wisdom are indefinite, ambiguous, and highly subjective. Politics is an art, military science is a profession. No commonly accepted political values exist by which the military officer can prove to the reasonable man that his political judgment is preferable to that of the statesman. The superior political wisdom of the statesman must be accepted as a fact. ${ }^{12}$

Huntington's ideal of military/civilian relations distills down to two interlocking syllogisms, both sharing the same major premise:

- Major Premise: The less competent should defer to the more competent.

- Minor Premise 1: Compared with civilian leaders, military officers are more competent about the military means of state action.

- Minor Premise 2: Compared with military officers, civilian leaders are more competent about the civilian ends of state action.

- Conclusion 1: Therefore, civilian leaders should defer to military officers about the military means of state action.

- Conclusion 2: Therefore, military officers should defer to civilian leaders about the civilian ends of state action.

Huntington's logic is sound enough; if his premises are true, his conclusions are valid. And, if his conclusions are valid, then the problem of military disobedience disappears. If military officers and civilian officials are both operating properly in their respective spheres of occupational competence, no conflict between them arises. 
This, alas, is obviously too good to be true; more precisely, it is too good to be always true. The real contribution of Huntington's analysis lies in its corollaries: what military officers and civilian officials are to do when ideal conditions are not met. We turn to those corollaries in Part II. As we shall see, Huntington's model, properly adjusted, offers principled limits on the obedience of military officers in two decidedly second-best scenarios.

\section{PART II: THE LIMITATIONS ON MILITARY OBEDIENCE IMPLICIT IN HUNTINGTON'S MODEL}

As Huntington's model identifies separate spheres of military and political expertise, so it divides the problem of military obedience into two basic situations: when civilian authorities invade the military's proper sphere of expertise and when civilian authorities fail in their own proper sphere. In each case, Huntington's model implies principled limits on military obedience. But, in both cases, the full strength of Huntington's model only becomes clear when important flaws of that model are sorted out. Part II takes up that task. In both cases, a better working out of Huntington's analysis offers a much better understanding of the limits of military obedience. We begin with the first situation, where the full implications of Huntington's analysis only need to be worked out, and then consider the second, where his analysis needs significant revision. 


\section{When Civilian Authorities Invade Military Officers' Proper Sphere.}

Recall that, under Huntington's Conclusion 1, civilian leaders are to defer to military officers in the latter's area of professional expertise, the use of military force. Now consider the possibility that civilian authorities do not defer under those circumstances, but instead usurp tactical control themselves. Huntington nicely isolates the issue:

What does the military officer do when he is ordered by a statesman to take a measure which is militarily absurd when judged by professional standards and which is strictly within the military realm without any political implications? ${ }^{13}$

His answer is unambiguous: "The statesman has no business deciding, as Adolf Hitler did in the later phases of World War II, whether battalions in combat should advance or retreat." ${ }^{14}$ And he is careful to make his answer a corollary to his earlier analysis:

The presumption of superior professional competence ... does not exist when the statesman enters military affairs. Here the existence of professional standards justifies military disobedience. ${ }^{15}$

But what, one might object, of the military officer's constitutional duty, in our very different American regime, to obey civilian authorities? Does not Huntington's model, even as it offers a limit to the officer's professional duty to obey, create a conflict with the officer's constitutional duty to obey? Here Huntington's model implies an answer that he seems not to have seen. His justification of disobedience in the case 
of militarily absurd civilian orders is not only professional, but also constitutional. As the Constitution's preamble reminds us, a fundamental purpose of our constitutional regime is "to provide for the common defense." That purpose, in turn, implies Huntington's functional imperative of military professionals: Provide the intellectual and moral pre-conditions for competent defense. Assisting in the implementation of fundamentally flawed tactics could, at least under some conditions, breach the officer's constitutional as well as professional duty. ${ }^{16}$

Consider, against this background, the situation in which General Eric Shinseki found himself as Army Chief of Staff in the Second Gulf War. Secretary of Defense Donald Rumsfeld and Deputy Secretary of Defense Paul Wolfowitz famously challenged Shinseki's professional estimate about the size of the force needed to occupy Iraq. ${ }^{17}$ Had Shinseki come to believe that he faced civilian orders to implement irresponsible tactics, occupying a hostile country with an inadequate force, he may well have considered himself constitutionally and professionally obliged to resist, even resign. ${ }^{18}$ In much the same way, military commanders might resist, on both professional and constitutional principles, politically motivated pressure from civilian authorities to put "boots on the ground" without tactically adequate support or reasonable prospect of military success in achieving even limited objectives. ${ }^{19}$

Nor is this potential reconciliation of professional and constitutional duty the end of the insight that Huntington's model offers. Just as the professional duty reinforces the constitutional duty, so the constitutional duty reinforces an even deeper moral duty. The constitution's invocation of common defense assumes a widely shared belief that self-defense is a basic right, personal and collective, moral as well as 
legal. The functional limit of an officer's professional duty to obey tactically disastrous civilian orders thus rests on a constitutional duty to defend the constitutional regime, which in turn rests on society's moral right of collective self-defense.

Huntington's analysis also entails, if only implicitly, another significant element: The limitation of the officer's duty to obey civilian orders within the area of military expertise is limited by the foundation upon which the rule and the exception both rest. To say, as Huntington does, that an officer is not professionally required to obey militarily absurd orders is, as he recognizes, to pose an extreme case. It may justify, as in the case of Hitler's generals, a response as extreme as "sabotaging, where possible, impossible policies." 20 But, from that limiting case, we can interpolate both lesser civilian incursions into the military's sphere and less radical responsive measures. Shinseki's fundamental disagreement over theater-wide tactics did not lead him to resignation, much less sabotage; a minor disagreement over tactics might lead an officer not to resign his or her commission, but to remonstrate with the relevant civilian authorities. ${ }^{21}$

The point here is not to say that the proper course of an officer's conduct in the face of a civilian usurpation of military tactical expertise is always easy to assess. More often than not, it will entail a complex assessment of overlapping duties and second-order effects. ${ }^{22}$ The point, rather, is that considerations often seen to be in conflict-professional competence and constitutional duty-can sometimes be reduced, in practice as well as in principle, to a common denominator: the common defense and the common good.

Huntington's theory of professionalism thus gives a well-grounded exception to the general rule 
of military obedience to civilian orders in the case of tactically flawed orders, an exception the limits of which are traceable to the policy underlying the rule. Against that background, we can now turn to Huntington's second conclusion: In matters of state ends, as opposed to military means, officers should defer to statesmen's greater expertise.

\section{When Civilian Authorities Fail in Their Own Proper Sphere.}

As we have seen, Huntington's first conclusionthat civilian authorities are to defer to the greater expertise of military officers in the latter's sphere, the management of violence-has its complement in the civilian sphere: Officers are to defer to the superior political expertise of statesman. So, we must now see, just as the first conclusion implies limits on military obedience, so does the second.

We need to notice, however, that the two sets of limits implied by Huntington's two conclusions are not perfectly symmetrical. In the case of military expertise, the limitations on the officers' duty to obey flow from the civilians' excursion into the military's proper sphere. In the case of civilian expertise, the limitation on the officers' duty to obey flows from the civilians' failure in their own proper sphere. The problem in the first situation is that civilian authorities are not following the logical conclusion of Huntington's analysis; they are not acting on the mandate to defer to military officers' greater expertise in military matters. The problem in the second situation is that civilian authorities are not meeting the logical conditions of Huntington's analysis; they are not providing expertise in statecraft. 
The trouble with syllogisms, of course, is that their conclusions are valid only if all of their premises are true. The problem with the second conclusion of Huntington's double syllogism is that Minor Premise 2 is demonstrably false much, if not most, of the time. ${ }^{23}$ Contrary to Minor Premise 2, military officers are sometimes better at assessing state ends than are civilian leaders, both because civilian leaders are sometimes poorly versed in matters of statecraft and, conversely, because military officers must be well versed in precisely those matters. ${ }^{24}$

Thus Huntington's second minor premise, the assumption that civilians are always more competent than military authorities in matters of politics, contains two dubious subpremises, one a universal positive, and the other a universal negative. First, civilian authorities are always politically competent; second, military officers are never politically competent. Each of these subpremises, as we will see in this section, admits obvious exceptions.

What is more, the premise of statesmen's superior competence in the political sphere may be false at either of two different levels of analysis, because the science of statecraft has two essential components: achieving state ends and evaluating state ends. With respect to both of these components of statecraft, civilian leaders are sometimes less competent than their military counterparts. Part II questions Huntington's presupposed superiority of civilian leaders to military leaders in the political sphere, first in achieving state ends, and then in evaluating state ends. Both assessments rely primarily on Huntington's own examples to show that his assumptions about the relative competence of military officers and civilian leaders are often demonstrably, even disastrously, false. 
Competence in Achieving State Ends.

Most of the case Huntington makes for the subordination of military to civilian leaders in the political sphere rests on arguments about statesmen's greater competence in achieving, rather than evaluating, state ends. We begin, accordingly, with the former.

\section{The False Subpremise of Universal Civilian Competence.}

As we have seen, Huntington's conception of competent statesmanship has two components: "a broad awareness of the elements and interests entering into a decision" and "the legitimate authority to make such a decision." ${ }^{25}$ The first thing to notice is that, as a matter of both fact and logic as well as law, a civilian leader may have legitimate authority without the requisite knowledge.

Hitler, again, nicely illustrates the point. Some legally legitimate rulers are, by no reasonable measure, "statesmen"; they are demonstrably maniacs. Nor is Hitler a single anomaly here. The last century, Huntington's century, also gave us Joseph Stalin, Benito Mussolini, Mao Zedong, Pol Pot, and Idi Amin. All had, at least at some point, legitimate authority under international law to make decisions about state ends. But notice, critically, that none had the other mark of Huntington's statesman: "a broad awareness of the elements and interests entering into a decision." Leaving aside, for now, their skill in evaluating state ends, they were not particularly adept at achieving those ends. 
To show that some political leaders are not proper statesmen is only to show that Huntington's premise about superior civilian expertise is not universally true - that it admits notable but perhaps narrowly limited exceptions. But Huntington does little, if anything, to prove that civilian politicians are proper professional statesmen more often than not. The closest thing he offers to proof of the proposition's truth comes down, in essence, to an argument that it needs to be true not only as a grounds for his theory's subordination of military to civilian authorities, but also as a guarantee of proper civilian government.

In the place of evidence that civilian politicians are the properly professional statesmen that his theory needs them to be, Huntington only offers evidence of when and why that need arose. Here is that evidence, which Huntington quotes from Field Marshal Earl Wavell's The Good Soldier:

Interchangeability between the statesman and the soldier passed for ever, I fear, in the last [nineteenth] century. The Germans professionalized the trade of war; and modern inventions, by increasing its technicalities, have specialized it. It is much the same with politics, professionalized by democracy. No longer can one man hope to exercise both callings, though both are branches of the same craft, the governance of men and the ordering of human affairs. ${ }^{26}$

Several factual assertions are confusingly conjoined here; once we tease them out, we find no reason to believe that civilian leaders are invariably, or even usually, the model statesmen that Huntington's model needs them to be.

The first assertion is that, under 19th century conditions, military leadership had to be professionalized 
if it were going to succeed, to meet what Huntington identifies as its "functional imperative." We can easily grant that Huntington has elsewhere proved that first assertion. The problem lies in the second assertion, that civilian leadership underwent a similar transformation: "It is much the same with politics, professionalized by democracy." ${ }^{27}$ Even if the independent clause is true, and politics came to require a professionalism paralleling military professionalism, the modifying phrase is very dubious evidence. Huntington needs that phrase to establish two propositions: that democracy somehow made professional statesmanship necessary and that politicians are true professionals.

The first proposition - that democracy made professional politics necessary - is at best unlikely. More likely, what made professional politics necessary were the same social factors that made military professionalism necessary: the increasing complexity of the task at hand, owning to a host of scientific and social factors, of which democracy was only one, and perhaps not the most critical one. As Huntington's own citation of Otto von Bismarck implies, political authorities needed to be statesman even in nations that were far from being democratic.

The second proposition - that democracy somehow ensures that modern political leaders must be competent statesmen-is both the more important and the more dubious, as surprising as it is unexplained. At least since the century of Plato's Republic and Thucydides's Peloponnesian War, the notion of a class of recognizably professionalized statesmen has been seen as, if not antithetical to democracy, then at least in tremendous tension with democracy. Huntington's own examples of this new and necessary division of labor only compound the problem. 
"Napoleon embodied the old unity of military science and politics. He was replaced by Bismarck and Moltke[,] who symbolized the new dichotomy." 28 Let us assume, with Huntington, that Bismarck was nothing if not a genius at realpolitik and that his military doppelganger, Helmuth von Moltke, was a worthy Clauwitzian master of war as "politics by other means." But Bismarck's statesmanship, whatever its merits, is hard to see as either produced or guaranteed by democracy. Bismarck would not likely have thought to submit his chancellorship to a plebiscite, and not only because he might well have lost.

The problem with Huntington's analysis of political professionalism, or statesmanship, comes to this: Technology- and demography-driven changes in the 19th century may well have made professionalism functionally necessary in both military command and civilian administration; this trend toward professionalization, in turn, may well have made it unlikely that any one person could be a master of both military science and civilian administration. But the emerging need for professionalism in both fields, military and civilian, does not prove that need has been met in either field. Nor did the concurrent trend toward political democracy mean that civilian leaders at the highest levels would tend to be, in any sense, professionals or experts at anything other than getting elected.

This suggests a possibility that, curiously enough, Huntington failed to mention, if not consider. Although military officers may need both elements of professional knowledge, Freidson's marriage of the technical and the liberal, ${ }^{29}$ civilian statesmen may need only one, the liberal, or, if anything more, only a sort of on-the-job ability to choose professional subordinates. ${ }^{30} \mathrm{~A}$ corollary would be that although states- 
men may well lack the qualifications to be officers, officers might well possess the qualifications to be statesmen. It cannot have escaped Huntington's notice, and he cannot have expected it to escape his readers', that, even as he was publishing his book, Dwight Eisenhower, the former Supreme Allied Commander, had just begun his second term as President of the United States.

That would still mean, of course, that civilian authorities might lack the educational requirements of statesmanship. Nor, as Huntington's own examples remind us, is that the worst of it. Civilian leaders may not merely lack any policy expertise of their own; they may eschew reliance on such expertise altogether, sometimes explicitly, sometimes implicitly, but nonetheless unmistakably. Here again, Hitler is the perfect paradigm:

Hitler was a mystic, who tended to discount, even when he did not disregard, all the rules of strategy.

Hitler taught and believed that reason and knowledge are nothing, and that the unbending will to victory and the relentless pursuit of the goal are everything. Mystical speculation replaced considerations of time and space, and the careful calculation of the strength of one's own forces in relation to the enemy's. All freedom of action was eliminated. Even the highest commanders were subjected to unbearable tutelage. ${ }^{31}$

Although Hitler is, as usual, the limiting case, his case is hardly unique. Fascism generally "stress[es] intuition" and "ha[s] little use or no need for ordered knowledge and practical, empirical realism," "celebrat[ing] the triumph of the Will over external obstacles." 32 Fascism, a sadly hardy perennial among 
political ideologies, illustrates a more general problem: Civilian authorities who rely not on greater policy expertise but on deeply and manifestly, even admittedly, irrational modes of decisionmaking.

Of course, even if civilian leaders eschew relying on expert policy analysis, they may nonetheless be willing to distort policy analysis in order to bring others, in the military and elsewhere, around to a position they have reached by their own irrational methods. This seems to have been significant in Hitler's overcoming his generals' objections to his plan to invade Russia:

Hitler was able to overcome their doubts about his Russian adventure with the aid of political "information" designed to convince them of its necessity, and that Russia's internal weakness would affect her military strength..$^{33}$

That was most likely not destined to be the last time that civilian authorities, bent on a military adventure for reasons unrelated to any rational analysis of the national interest, overstated both the threat posed by an enemy and the weakness of that enemy's internal support. ${ }^{34}$ As we shall see in the next section, a military officer corps well versed in geopolitical matters may provide the best bulwark against such deceptions and attendant disasters. ${ }^{35}$

\section{The False Subpremise of Universal Military Incompetence.}

As we have just seen, civilian politicians often lack or ignore the knowledge base necessary for the function Huntington's model assigns them as "statesmen"; now we need to see that, in Huntington's own 
account, military officers functionally need, and often actually have, just this knowledge. This is a second challenge to the minor premise of Huntington's argument for universal deference of military officers to civilian policy determinations, the notion that military officers necessarily lack political expertise.

To appreciate this second challenge, we need to note that Huntington's version of military professionalism entails two essential parts: tactics, the variable components of managing violence, and strategy, the constant components. ${ }^{36}$ Military officers must master both tactics and strategy if they are competently to use military force to achieve state ends. ${ }^{37}$ Those ends are, as we have seen, the arena of statesmen's special competence, politics or policy in Huntington's model. ${ }^{38}$ In trying to distinguish the sphere of the officer from that of the statesman, Huntington has to make a significant concession: "Obviously a considerable area exists where strategy and policy overlap." 39

To fulfill their functional imperative, officers must know not only strategy and tactics, how to use military means in service of state ends, but also how the use of military means will affect state ends and be limited by them. As Huntington insists, "the military man must recognize that a wide number of conceivably purely military decisions, such as the selection of a theatre of war, also involve politics, and he must be guided accordingly." 40 Think, again, of Hitler's blunders: Bad as Bolshevism on the Reich's eastern border may be, it would be worse to force Stalin into an alliance with the western capitalist democracies and open a very long second front. ${ }^{41}$ More generally:

The top military leaders of the state inevitably operate in this intermingled world of strategy and policy. 
They must always be alert to the political implications of their military attitudes. ... ${ }^{42}$

As Huntington nicely illustrates, military officers can, and often do, have access to political expertise of their own:

When required in his executive capacity to make decisions involving both military and political elements, the military man ideally should formulate his military solution first and then alter it as needs be on the advice of his political advisors. ${ }^{43}$

In those final phrases, not emphasized in the original, Huntington seriously undermines his own "division of labor" argument for military deference to civilian political expertise. Even if no one person can master both military "science" and political "art," a military officer can refer to political experts within the military. Even assuming, with Huntington, that military officers cannot be experts on policy, they can, by his own admission, have political advisors of their own, presumably on their staff. Acting on the analysis of these advisors, military officers could plausibly question the policy decisions of civilian leaders and their civilian advisors.

In fact, Huntington assigns the military two essential functions that entail just such political assessments. The first of these is what he calls the representative function. In performing this function, the military officer "must keep the authorities of the state informed as to what he considers necessary for the minimum security of the state in the light of the capabilities of other [military] powers." 44 This function entails: 
the right and the duty to present his views to the public bodies, whether executive or legislative, which are charged with the apportionment of resources between the military and other claims. ${ }^{45}$

The second of these functions is what Huntington calls "the advisory function." In performing this function, the military officer is "to analyze and to report on the implications of alternative courses of state action from a military point of view." 46

In any of their three capacities - the executory, the representative, or the advisory - military officers could find their political analysis at odds with those of a civilian leader. ${ }^{47}$ In at least some cases, the military officers might reasonably conclude that their own political assessments, or those of their political advisors, are superior to those of their civilian counterparts. Think only of Wolfowitz's congressional testimony, in the face of Shinseki's troop estimates, that "there was no history of ethnic strife in Iraq, as there was in Bosnia or Kosovo" and that "Iraqi civilians would welcome an American-led liberation force." 48

Even more basically, military officers could recognize situations in which civilian leaders are not acting on political expertise at all, even as Hitler's generals recognized with his decision to invade Russia. Even if it were true, as Huntington insists, that military officers must "be willing to accept the final decision of the statesman," 49 it doesn't mean they have to follow the final judgments of political authorities who are not statesmen; even in the case of those who were, he would need to give an independent reason for obeying them when their political decisions conflicted with those of equally reliable political experts, in or out of the military. 
Huntington's argument for the general deference of military to civilian authority on policy decisions assumes a universally superior competence of civilian authorities to military officers that is, on Huntington's own evidence, demonstrably false in many significant historical cases. What is worse, Huntington gives no evidence to support his basic premise that civilian authorities are generally more expert in political matters than their military counterparts and more reliable in the achievement of state ends, and thus to be deferred to on that basis. Next, we need to examine an even worse problem with his argument for general military deference to civilian authority: the hidden assumption that civilian authorities are not only better at achieving state ends, but also at choosing or evaluating state ends.

\section{Competence in Choosing State Ends.}

Expertise in using military force and other means to accomplish state ends is only one aspect of the statesman's supposedly superior knowledge. The other aspect is evaluating state ends. We have just seen that Huntington's argument for military obedience to civilian authority rests on a claim that civilian authority is always better versed on the relation of military means and state ends, a claim that is demonstrably false in many cases, and doubtful in principle across an even wider range. With respect to evaluating ends, as with respect to matching means to ends, we have no reason to believe that civilians will always be right and officers always wrong. Any claim to civilian superiority in the evaluation of ends shares all the problems with claims about the matching of military means to civilian ends and compounds them with a deeper problem long familiar to normative philosophers. 
The special problem of evaluating ends is neatly captured in Emmanual Kant's distinction between hypothetical imperatives and categorical imperatives. ${ }^{50}$ With respect to hypothetical imperatives, the end entails the necessary means to that end. One may or may not want the end, but, if one does want it, one also wants, ex hypothesi, the necessary means. To use Stalin's chilling example, if you want an omelet, you must break some eggs. If your chosen end is an omelet, you will necessarily be breaking some eggs; if you are a vegan, you will be getting your breakfast protein from another source.

Stalin, of course, was not really talking about eggs. Making omelets was his metaphor for his murderous domestic policies. We remember it because it anticipates, even as it scorns, an obvious objection: Human beings are not eggs. Even if we cannot quite work out either the logic or the full implications of Kant's argument that human beings are ends in themselves, we can feel the attraction of its negative corollary: Human beings are never to be used only as means to the ends of others. To derive from our own rationality an absolute, or categorical, imperative to treat rational nature, in ourselves and others, always as an end in itself may be a bit ambitious; that, indeed, is very much the point we need to see.

No one doubts that we live in a world of hypothetical imperatives, from the preparation of breakfast to the conduct of diplomacy. It makes perfect sense to say, as Huntington does, that the accomplishing of state ends entails special imperatives beyond the ken of all but the expert: defending the homeland, managing the economy (or leaving it alone), running a legal system. But, as we have seen, it cannot plausibly be said, as Huntington does, that civilian authorities are always better at ends-means rationality than anyone 
else; sometimes civilian authorities make mistakes that military officers are quite qualified to spot.

What we need to see here is that it is even less plausible to say that civilian leaders are always better than anyone else in choosing what ends to pursue in the first place. Military leaders, as experts in the management of violence, can sometimes see that civilian political choices will result not in the ends desired, but in the very opposite, the destruction of the regime. Military leaders, as people of ordinary moral sensibility, can see that some ends are deeply disturbing, even outright unacceptable, for them as individuals and for any society of which they could agree to be a functioning part. ${ }^{51}$

Here again, Nazism proves an important reductio of Huntington's analysis. Hitler, he has to admit, proved a very poor statesman in the actual accomplishment of state ends; among other things, his political rashness led him to invade Russia prematurely and thus to open a second front that may well have been his undoing. But consider, now, the alternative. Suppose Hitler had been a savvier grand strategist, had honored his nonaggression pact with Stalin until he defeated the Western allies (or developed the V2 or the atomic bomb or the jet fighter), and had only then turned east to conquer the Soviet Union, thus securing domination of Europe (and, had he shown similar savvy in dealing with Japan and the United States, perhaps the world). Could we, consistent with Huntington's analysis, call him a great statesman? If we are to deny Hitler that accolade, we must be ready to distinguish between achieving state ends and evaluating those ends, choosing state ends that are worthy.

Here we see a glaring omission in Huntington's analysis of statesmen, particularly in comparison with 
his military officers. Military officers must have not only special, professional knowledge, but also a special, professional virtue that ensures they do not abuse that knowledge. Huntington insists that civilian leaders have a corresponding kind of professional knowledge; sometimes, as we have seen, they do not have that knowledge. Here we see something different. Civilian leaders, like military officers, need a special virtue as well, a virtue that ensures that they do not use their special expertise in the achieving of state ends to achieve ends that are bad, in either of two easily identified ways: bad because they threaten to destroy the civilian population in order to advance regime goals, as in the case of Hitler's "Nero orders," or bad in the sense that they threaten to destroy the system of international relations, as in the case of Nazi ambitions of continental, even world, dominance. In tacit recognition of the need for some such limits, Huntington offers two exceptions to his rule that military officers always obey the orders of legitimate civilian authorities, exceptions still echoed in today's debates. 


\section{PART III: TWO EXCEPTIONS TO MILITARY OBEDIENCE THAT PROVE A MORE BASIC RULE FOR BOTH MILITARY OFFICERS AND CIVILIAN AUTHORITIES}

Huntington recognizes two exceptions to the military officers' obligation to obey civilian authorities in political matters, the proper sphere of civilians: when those authorities act illegally or immorally. ${ }^{52}$ Both these exceptions undermine his general rule of obedience, even as his effort to narrow these exceptions underscores his exaggeration of that rule. ${ }^{53}$ The problem in the case of both illegality and immorality is the same problem we have already identified: Military officers may be better judges in these matters than their civilian counterparts, because both matters entail determining the public good. Thus, in effect, what begin as exceptions to the rule of universal military obedience take us back to exactly the same point where our analysis of that rule took us: Military officers, to perform their professional duty to defend the homeland, must know and act upon both the constitutional and the moral bases of that duty, the common good.

\section{The Legality Exception: Officers' Duty to Disobey Illegal Civilian Orders.}

Huntington admits the first of his exceptions in the case of conflict between military obedience and legality. In matters of law, as in matters of both warcraft and statecraft, the question of deference turns on occupational competence. Thus:

If the statesman claims to be acting legally, but the action seems illegal to the officer, then the issue is one of 
the relative competence of the officer and the statesman to judge what is legal and illegal. ${ }^{54}$

Since law, strictly speaking, lies outside the expertise of both military officers and civilian statesmen, the ideal recourse, in modern states with an independent judiciary, is to the courts. ${ }^{55}$ In the absence of that option, "the military officer can only study the law applicable to the situation and arrive at his own decision," recognizing a duty "to give a considerable presumption of validity to the opinion of the statesman." 56 To distinguish his refusal to recognize a parallel possibility with respect to military review of civilian policy decisions, Huntington asserts that "the standards of law are generally more precise than those of politics but less than those of military science." 57

Whether or not he is right about the relative precision of the standards of law, politics, and military science, he is certainly wrong to suggest that "the military officer can only study the law applicable to the situation and arrive at his own decision." In fact, in law, as in statecraft, military officers, every bit as much as civilian authorities, are able and likely to rely on the assessments of their own legal experts. That was precisely what happened in the now infamous case of enhanced interrogation. Military officers and civilian authorities both turned to their legal advisors; military and civilian lawyers disagreed on whether "enhanced interrogation" amounted to statutorily forbidden torture. On more precise legal points, as on broader policy points, the military lawyers may well have had the better view. ${ }^{58}$ 
Huntington's focus on these more precise questions of law ignores another parallel between law and politics, which parallels a distinction we drew within politics. ${ }^{59}$ American constitutional law (and, more generally, any other form of liberal law) imposes two basic constraints on all state action. It must serve legitimate state ends, and the means it employs must be rationally related to those legitimate ends. Our actual legal system, then, like Huntington's ideal political system, contains minimum standards for assessing both the means used to advance state ends and those ends themselves. Stated at an admittedly rarefied level of generality, these are the standards: The means of state action must bear at least some plausible causal relationship to the ends they purport to advance; those ends must be grounded in the common good and trammel no more than necessary certain traditionally recognized conditions of human flourishing.

To illustrate these common floors under both legal and policy analysis, consider again the question of enhanced interrogation. Even if the civilian lawyers were correct in concluding that enhanced interrogation was not illegal in the narrow sense that it did not violate the relevant statutory prohibition on torture, that still leaves deeper legal questions open. The practice of enhanced interrogation might well have violated constitutional requirements of substantive due process, in either of two ways. First, it might be that the use of enhanced interrogation demonstrably does not work, that enhanced interrogation as a means of extracting useful information is contrary to any conceivable explanation of human psychology. ${ }^{60}$ Given the narrowness of this test and the practical plausibility of enhanced interrogation, the policy may perhaps pass this first test, even if that policy is, on balance, 
a very poor way of extracting information. It could, in that sense, be "bad policy" but still "good law," a functionally inferior but not wholly ineffectual measure that thus satisfies the minimal constitutional standard of ends/means rationality.

But that would still leave the other, ends-oriented constitutional test: Even if enhanced interrogation is a marginally effective method, is ours a state that can use human beings, prima facie "ends in themselves," as means in this way without violating rights we deem fundamental? Here, of course, the answer is less clear as a matter of law. But it is indeed a matter of lawnot merely politics - and legal questions are no more precise at this level than political questions because here our politics and law converge. A fundamental function of our law, like all liberal law, is to limit our politics (at least provisionally, pending constitutional amendment).

This returns us to an earlier point: the relative expertise of military officers and civilian authorities. On legal matters here, as on political matters earlier in our analysis, the opinions of military officers and the experts on their staff may be superior to those of civilian authorities at every relevant level of analysis. As others have shown in painful detail, the Justice Department's "torture memo" was a model of dubious statutory interpretation. ${ }^{61}$ More basically, however, the military's assessment seems to have been better at the two levels of ends/means rationality common to both constitutional law and political statecraft. Torture, as the military argued, may be a poor means of obtaining operationally useful information; it may well fail the basic test of ends/means rationality. ${ }^{62}$ As a matter of evaluation of state action, torture may fail as a matter of choice of state ends: We may not want to 
be the kind of people that torture other people (at least under the conditions no more restricted than those presented by this situation), and our constitution may well place that deep preference beyond the reach of ordinary politics.

The issue of enhanced interrogation also raises a point that Huntington's analysis seriously underemphasizes. The law that limits our politics, and thus our military officers' duty to obey our politicians, is not our law alone; the law that governs both our civilian authorities and our military officers alike is international as well as domestic. Enhanced interrogation looks, at its uglier extremes, a lot like torture; torture is forbidden by international treaties as well as by domestic statutes and constitutional norms. ${ }^{63}$ Torture, along with a growing list of other human rights violations, may well rest on an even deeper stratum of international law. It may belong, with genocide and offensive war, to the class of prohibitions binding on all state agents, even those whose nations have not endorsed those norms as their own. Think, again, of Hitler's generals.

The case of enhanced interrogation illustrates the situations in which military officers might have reason to question the legality of particular civilian orders, under both national and international law. To his credit, Huntington also addresses, if only briefly, the more basic question about the legality of the civilian authority. Not only are military officers, under Huntington's model, obliged to disobey illegal orders; they are, more generally, obliged only to obey the orders of legitimate regimes. The question of a regime's legitimacy is to the question of an order's legality as wholesale is to retail. Particular orders of a legitimate regime may be illegal, and in that sense not binding 
upon officers; no orders of an illegitimate regime may, of their own force, be binding on officers, because the regime is not a source of proper law. Without unpacking this latter jurisprudential paradox, we can note that illegality at the wholesale level, the problem of illegitimate regimes, poses deeper problems for Huntington's analysis than he admits, or perhaps appreciates.

Huntington confuses the question of legitimacy even as he raises it:

If there are two governments in the state, each claiming to be duly constituted and to be deserving of military obedience, the military officer cannot escape the political choice between the two. ${ }^{64}$

This is not quite correct, even in Huntington's terms. Some putative governments utterly lack legal authority, under either domestic or international law; sometimes, as Huntington suggests elsewhere, legal questions are, indeed, more precise than political questions. But, here again, at the "wholesale" level as at the "retail," questions of legality blur at the margin into broader political questions.

Here at the wholesale level, we need to note, the line blurs in a more basic way. As a matter of international law, the legitimacy of a political regime turns, in large part, on its effective control of the territory it claims to govern. ${ }^{65}$ Here, the military must not merely assess law at its intersection with policy; the military's policy-based actions may well determine the legality of the regime it is to serve. Revolutions often turn on whether the military turns its weapons on the people in the street or the rulers in the capitol. Marshal Philippe Petain made his peace with Hitler and 
moved his capital to Vichy; General Charles de Gaulle insisted that his "Free French," though in exile, were the legitimate rulers of France. The political choice that military officers face in this situation, we need to notice, is theirs as a practical matter, but that is not to say, as Huntington implies, that it is not capable of principled review.

Indeed, Huntington's model implies precisely the reverse. Military officers' decisions about the legitimacy of the regime (like their decisions about the legality of particular orders of an unquestionably legitimate regime) rest on reviewable principles. Their decisions also rest on the same principles as the military's professional role and the state's proper role-protecting the basic security of its own people (and, conversely, not threatening the basic security of other peoples by actions like offensive war or genocide).

Thus, in effect, Huntington's analysis places military officers under three imperatives, not just two. In addition to their professional imperative to deliver effective defense and their legal imperative to preserve the Constitution, they also have a humanitarian imperative, which underlies both: In the means you use to defend the state, and in the ends of the state that you advance, do not violate international restrictions on the use of violence. As the example of the Nazi officers makes clear, the penalty for violations can be the severest possible: capital punishment. As the example of Nazi Germany and Imperial Japan also make clear, the penalty for the regime can effectively be the same: loss of legal legitimacy under international law and "regime change." 66

The most basic point to note here is that both international and domestic law, at this deepest level, incorporate humanitarian moral principles. Thus the limit- 
ing case of Huntington's first exception to his general rule of military subservience, illegal orders, brings us to his second exception, immoral orders, which proves both broader and deeper.

\section{The Morality Exception: Officers' Duty to Disobey Immoral Civilian Orders.}

Huntington's second exception to his general rule of military deference to civilian policy decisions is "the conflict between military obedience and basic morality." ${ }^{67}$ "What," he asks, "does the military officer do if he is ordered by the statesman to commit genocide, to exterminate the people of an occupied territory?" 68 One who has not already analyzed Huntington's peculiar understanding of "statesman" might be surprised by a question presupposing that statesmen do order genocide. Even after that analysis, Huntington's answer is still at least a little surprising. He never explicitly rules even genocide out entirely; he merely gives officers the option to disobey an order that violates the officer's personal morality.

The argument that leads Huntington to this narrow morality exception to his general rule of military obedience is a page of rousing rhetoric. Only after we defuse its rhetorical power can we appreciate its logical limits. In what follows, I omit nothing of Huntington's discussion and quote nothing out of his order; I merely interrupt it with my own commentary. This is not, of course, entirely fair to Huntington; all I do here is to transpose his admittedly stirring rhetoric into a pitch that is off-puttingly shrill. But Huntington could hardly cry foul; I am, after all, only returning his sophistical fire with my own, borrowing a page from $\mathrm{Ar}$ istotle's Rhetoric on the oldest trick of sophistry: Meet 
the serious with the comic, and the comic with the serious. ${ }^{69}$ And, after exposing the rhetoric, I return to rational analysis, which Huntington can hardly claim to have attempted in his own treatment of the topic.

Huntington chooses the field of his mock battle and arrays his forces brilliantly. By charging military officers with a civilian order to commit genocide, he places them on what seems to be very high moral ground, both relative to civilians and absolutely, ground they not only can hold, but must:

So far as the ability to judge and apply ethical standards are concerned, the statesman and the soldier are equal. Both are free individuals morally responsible for their actions. The soldier cannot surrender to the civilian his right to make ultimate moral judgments. He cannot deny himself as a moral individual. ${ }^{70}$

Both the very humanity of others and the officer's own moral integrity-or, perhaps more precisely, manhood-are under attack; the officer, accordingly, cannot surrender.

Suddenly Huntington's bugle ceases its blare. "Yet the problem is not so simple as this ... For politics as well as basic morality may be involved here." Not, of course, the coarse and corrupt politics of politicians, but the high, and highly principled, politics of statesmen, wise and honorable fellow experts with sacrifices of their own to make:

The statesman may well feel compelled to violate commonly accepted morality in order to further the political interests of the state. That this is frequently the case, there is no denying. ${ }^{71}$ 
Just as the professional soldier is about to join battle on the twin peaks of moral liberty and liberal humanity, Huntington subtly shifts both the lay of the land and the alignment of forces. Before, military officers stood, second to none, not only for their own personal honor, but also for the intended victims of genocide. Now that apocalyptic beast is nowhere in sight; its innocent victims, the weak and the helpless, are no longer in imminent peril.

In the place of evil incarnate and innocence violated appear two abstractions. One, "the political interests of the state," is not only less loathsome than genocide but also also the very highest value of the military profession. And the other abstraction, commonly accepted morality, is a lot less lovable than the now-vanished victims of genocide. Indeed, the modifiers of morality remove from its appeal at least as much as they add. "Common" means "low" and "frequent" can also mean "universal." "Accepted" is far removed from "proved."

What is more, Huntington reminds his officers that, in this newly defined battle, they face not an enemy but an ally, the statesman, a fellow servant of the public good. Huntington asks the loyal soldier to see the new situation from that ally's perspective:

If the statesman rejects the private claims of conscience in favor of the raison d'etat, is he also justified in implicating the military man too, in subordinating, in effect, the military man's conscience as well as his own? ${ }^{72}$

From that perspective, the front of battle is no longer what first it seemed. Orders to commit genocide fade into the background as Huntington's argument advances along a very different line. What the sol- 
dier faces is not the enemy of humanitarian morality, but the ally who shares his own morality, and an ally who is ready to sacrifice even his own morality for the greater good, the public good to which the officer is pledged. This is not a contest of wills, the soldier's own against some other's; what this situation demands is not surrender to an enemy, but self-sacrifice to a common cause. The real enemy, it now appears, is a fifth columnist in the officer's camp, the source of division is the soldier's loyalty, which is an insinuating call away from public duty to private opinion, if not quite self-indulgence. "Basic morality," which had already slipped to "commonly accepted morality," now blurs into "the private claims of conscience."

For the officer this comes down to a choice between his own conscience on the one hand, and the good of the state, plus the professional virtue of obedience, on the other. As a soldier, he owes obedience; as a man, he owes disobedience.

The course for the good soldier is, accordingly, clear. Huntington's bugle sounds again, and one wonders that the outcome can ever have been in doubt:

Except in the most extreme instances it is reasonable to expect that he will adhere to the professional ethic and obey. Only rarely will the military man be justified in following the dictates of private conscience against the dual demands of military obedience and state welfare. ${ }^{73}$

This is rhetoric to rival Churchill and all the more reason to notice that Huntington's conclusion runs, ultimately, rather in the opposite direction. As Churchill has all English-folk fighting Nazis in the fields and the 
streets, and if necessary in the hills, where they will never surrender, so Huntington gives his officers the moral high ground, allows no superior in its defense, and permits no surrender. But Huntington narrows his high moral ground to the vanishing point, undermines it completely, and leaves his officers standing there not only divested of their military status, but also in full defiance of professionally unquestionable orders. At the end of Huntington's analysis, the officer is no longer fighting the good fight, past the last ditch, at the last redoubt, to the very end. He is more like Don Quixote, tilting at illusory windmills, and even more like an ancient stylitic saint, perched on a pole of his own erection, naked and alone in a very peculiar, if not pointless, position.

This is, again, not entirely fair to Huntington; I have done nothing but grind his high drama down to low farce. But to score debating points is neither Huntington's ultimate goal, nor mine. He needs to show not only that his morality exception is narrow, but also that it proves his general rule of military obedience to civilian orders; to do that, he needs to keep that exception as narrow as possible and to ground it in the reason for the general rule itself, the relative occupational competence of military officers and civilian statesmen. I need to show that the morality exception is not only wider than Huntington allows, but also deeply subversive of his general argument for the rule.

To give Huntington his due, we must now do what he, for whatever reason, declines: Isolate and analyze the reasoning that underpins his rhetoric. Once we examine the steps in this analysis closely, bearing in mind Huntington's own genocide example, we can see major problems at several critical points: underweighing moral matters as compared to political matters, all 
the while insisting that the two are commensurable and that civilian authorities are better at striking the proper balance. Identifying these problems suggests a very different weighing of the relevant factors, moral and political, and a very different conclusion about whose scales are more reliable, military or civilian.

Huntington's rhetoric implicitly assigns civilian authorities and military officers a set of parallel tasks. The civilians' tasks logically come first; it is civilians who, in Huntington's model, are the ultimate ground of all military orders, even as they are the source of his particular example, the order to commit genocide.

- Step One: Separating moral from political considerations. The civilian authorities must separate moral considerations from political considerations, matters of private conscience from matters of public welfare, as a logical first step in assessing one against the other.

- Step Two: Determining raison d'etat. Here the civilian authorities, in their official capacity, weigh up all the nonmoral costs and benefits of the state action under review. If these net out negative, they reject the proposal, and the analysis ends; if raison d'etat net out positive, they go on to Step Three.

- Step Three: Measuring morality. Here the civilian authority weighs all the moral costs and benefits of the proposed action. This step, as compared to Step Two, has several notable peculiarities. The moral factors and their weighing are, ex hypothesi, outside the scope of the statesman's professional competence; what is more, they seem to be ultimately subjective. No one else can "check the math" here, because everyone makes these calculations differently. 
For that reason, the civilian official performs this step in his or her personal, not official, capacity. If these moral considerations net out to be positive (or zero), they simply add more (or nothing) to the balance in favor of the action; then the civilian official's analytic work is done, and he or she goes to Step Five. If, on the other hand, these moral considerations net out in the negative, he or she goes on to Step Four.

- Step Four. Balancing moral costs against state benefits. Here the civilian authority must weigh the proposed action's net moral costs against its net nonmoral state benefits. This step, like its predecessor, has several notable peculiarities. First, the moral costs and nonmoral costs seem to be, by definition, incommensurable: moral costs are personal, subjective, and thus unreviewable. Nonmoral benefits are public; they are interests of the whole state and not of a mere individual. They are calculated according to expert criteria that, if somewhat subjective, more art than science, are nonetheless susceptible to review by other trained professionals (at least in principle). If the balance here tips in favor of benefit to the state, the civilian authority orders the action; if it tips the other way, the civilian authority must make a personal, private, and subjective decision about whether to put state interests ahead of personal morality. A very heavy thumb is obviously on the state's side of the scales, and, given the heavy discount to be applied to the other side, the balance is not likely to be tipped that way.

- Step Five. Issuing the order to the military. 
Military officers who receive an order implicitly subject it to a parallel, but significantly distinct, analytic process. Their analysis seems to go like this:

- Step One: Identifying a conflict between moral duty and professional duty. Military officers engage in moral analysis of an order only if they find a prima facie moral objection to the order.

- Step Two: Determining raison d'etat. Military officers do not independently weigh the costs and benefits of orders they receive from civilian authorities; instead, they take the civilians' assessments as valid, which is to say, as net positives.

- Step Three: Moral analysis. Here military officers, like civilian authorities, weigh up all the moral costs and benefits of the proposed action. For military officers, as for their civilian counterparts, this step is personal, not professional, both because moral factors and their weighing are, ex hypothesi, outside the scope of their professional competence and because these matters are ultimately subjective. If these factors net out positive (or zero), they simply add more (or nothing) to the balance in favor of the action; the military officers' analytic work is done, and they implement the order. If, on the other hand, the moral considerations net out negative, they go on to Step Four.

- Step Four: Balancing moral costs against state benefits. Here military officers, like their civilian counterparts, must weigh the action's net moral costs against its net nonmoral benefits. And, here military officers, like their civilian counterparts, must compare incommensurables: On the one hand, moral costs that are 
personal and subjective, both in value and in measurement, and rationally unreviewable; on the other, nonmoral state benefits that are public and objective, both in value and in measurement. But here military officers are at a distinct disadvantage. Unlike civilian authorities, they have no particular expertise in assessing nonmoral benefits. Civilian authorities, as professionals, know the proper weight of only one side of the balance, state benefits; military officers, as professionals, do not know the proper weight of either side.

Here, accordingly, military officers' best course is to defer to civilian experts; anything else entails not only a generally dubious failure to subordinate incompetence to competence, but also the particular risk of making a wrong judgment in the case at hand. What is more, even a "right" judgment here is doubly dubious: It involves a breach of professional duty, which entails elevating the personal over the public. This, we would do well to recall, was precisely Huntington's assessment of the generals who politically opposed Hitler. As a result, a proper military professional will defer except in very rare cases, which will always be something of a professional embarrassment.

- Step Five: Implementing the order.

We need to look at two aspects of this analytic process particularly closely. One is the relative expertise of military officers and civilians in weighing moral and political considerations; the other is the relative weight of those considerations. First, consider the question of relative expertise. Notice that Hunting- 
ton's analysis of military officers' obedience to immoral orders applies only to orders they receive from civilians. But, of course, military officers at every level issue many orders. As Huntington concedes, in issuing those orders, military officials must make appropriate weightings of all relevant factors, political and moral as well as military. In other words, in the case of all orders except those coming from civilian authorities, military officers must be following the first set of analytic steps, those of order issuers, not the second, those of order implementers. In issuing orders, every military officer must make precisely the same kind of assessments that civilian authorities are making in deciding whether or not to issue an order.

In claiming that military officers are thus at a disadvantage, vis-à-vis civilian authorities, in weighing moral concerns against state concerns, Huntington is assuming either of two untenable positions. He might be assuming that military officers, in deciding whether to issue their own orders, should make no assessment of moral considerations. This hardly seems likely. If they are to make those assessments in deciding whether to obey orders from others, orders with the weight of those others' independent weighing, then surely they should make that assessment in deciding what orders to issue. Huntington might, on the other hand, be assuming that, although they do make such determinations, they gain no insights or expertise in this weighing that might tend to put them on a par with civilians when they are faced with orders coming from civilians. This, too, seems unlikely, and, in any case, it is not a prospect that Huntington actually considers. Huntington's claim for the greater expertise of civilians in weighing moral against political concerns seems, at best, unproven and, at worst, at odds with a more likely account. ${ }^{74}$ 
If Huntington has not made the case for civilian authorities' greater expertise in moral and political matters, he does even worse trying to separate morality from politics and then to subordinate morality to politics. These latter problems appear as soon as we put Huntington's own example of genocide through his implicit analytic system. Here as elsewhere, the exception Huntington chooses to admit badly undermines the case he makes, in more abstract terms, for his general rule. Few see resisting genocide as either a matter of purely private conscience or an issue only for the morally squeamish; most, rather, think it must be part of a larger category of shared moral, even legal, concern than Huntington's analysis suggests. And genocide is only the limiting case on a spectrum of moral wrongs that, even if not ultimately subject to mathematical proof, are easily seen to violate widely shared humanitarian norms. A little this side of genocide is the notion that "life is cheap in the Orient"; short of killing all the people in a country, one can make that country an ecological wasteland; maybe a bit less bad than that, one can "bomb them back to the Stone Age."

In opposing these matters, reasonable minds-or, more precisely, minds that are both reasonable and humane-can and do tend to agree. This is just a special case of the general rule we have already seen: Statesmen are not necessarily better judges of state ends than military officers are. Accordingly, as Martin L. Cook concludes:

Unwillingness to render obedient service to policies an officer considers deeply flawed and utterly at variance with sound professional judgment is not necessarily evidence of a lack of professionalism but may on occasion be a high manifestation of it. ${ }^{75}$ 
Huntington's effort to reduce the moral weight on the military officer's side of the balance to mere individual opinion thus doubly fails. Sometimes military officers will have very good reason to think their civilian superiors are less competent to judge moral matters, and sometimes, as in the case of genocide, moral matters may be very weighty indeed. Huntington's effort to increase the weight on the civilian side of his analytic scale fails for precisely parallel reasons. Here, remember, his move is to stack the civilian side with weighty matters of state, their particular area of expertise. But, as we have seen already, civilian authorities may have no such expertise and, even if they do, they may lack the virtue to use that expertise for the common good. Under either condition, military obedience to civilian orders will predictably undermine, rather than advance, the common good. And, for the reasons we have noted, properly trained military officers are well-positioned to determine whether these two conditions exist.

\section{Reconciling Rule and Exceptions in Their Joint Foundation: The Common Good.}

The link between Huntington's illegality and immorality exceptions lies deeper than he means for his genocide example to suggest. ${ }^{76}$ Both exceptions take us back to the minor premise of Huntington's argument for the general rule of military obedience to civilian authority, the assumed superior occupational expertise of civilian authorities over military officers in matters of state welfare. Like the general rule of military obedience in that domain, the two basic exceptions to that rule turn on the issue of civilian authority's greater expertise. 
In legal matters, as we have seen, statesmen have no more expertise than military officers, and thus the latter's general obligation to defer to the former is, on matters of law, removed. But, as we have also seen, this concession tends to prove more than Huntington intends - that law is not just a parallel discipline entailing different expertise; it is also an independent constraint on civilian authorities. In moral matters, Huntington's argument about relative expertise does not produce (as he hoped) a much narrower exception than law. As we have seen, it produces a much broader exception, with the same basis at bottom: the common good. ${ }^{77}$

That, in turn, should remind us of what we saw with respect to the other half of Huntington's double syllogism, the duty of civilian authorities to defer to military officers in military matters. Just as there, in the sphere of military expertise, officers are sometimes justified in disobeying civilian authorities who intrude into an area outside their own expertise, so here, in the sphere of civilian expertise, military officers are sometimes justified in disobeying civilian authorities who lack their own appropriate expertise. Also, here as there, the military officers' professional duty and its legal and moral exceptions can be traced back to, and resolved in terms of, the same basis as civilian authorities' corresponding duty and its limit-serving the common good.

Again, here in the civilian sphere as there in the military sphere, the limits of the military officers' justified disobedience to improper civilian orders are to be measured by the same metric. Just as minor civilian intrusions in matters of military expertise should be met with less severe responses than major intrusions, so minor civilian lapses in legal or moral matters 
should be met with less severe responses than major lapses. We can thus say, with respect not only to issuing their own orders, but also in deciding whether and how to obey or disobey civilian orders, military officers act under a single rule: Do what advances the common good. And that, of course, is the same rule under which civilian authorities in a republican form of government are bound to act.

Finally, this does not mean it will always be easy for military officers to determine when civilian authorities have failed to follow that rule as it applies to them. More likely, that determination will never be easy. Rather, this means the factors military officers are to consider in both making that determination and in deciding how to respond to it - the professional, legal, and moral factors - must all ultimately be reducible to the common good, the common denominator of both civilian and military service in any proper republic.

\section{CONCLUSION: NOT A SIMPLE, MODERN ANSWER, BUT A UNIFIED NEO-CLASSICAL PERSPECTIVE}

Debate over the proper limits of military officers' obedience to civilian authority often assumes that three incommensurable sets of values are in play: moral, legal, and professional. As the debate is generally framed, officers have both a constitutional and a professional obligation to obey civilian orders; sometimes these duties conflict with each other, and sometimes either or both also conflict with the officer's independent moral duties. This monograph has not tried to solve all conflicts between military officers and civilian authorities but to offer a neo-classical perspective from which to reframe those conflicts. The focus here, 
following Huntington's The Soldier and the State, is the common good that both military officers and civilian statesmen, as professionals, are supposed to know and serve.

The preamble to our Constitution reminds us that ours is a republic - a government devoted to advancing the common good, of which the common defense and the general welfare are inseparable parts. The Founders were quite aware that the question of civilian and military relations was a subset of a larger question, finding and maintaining public officials, civilian and military, both knowledgeable of and devoted to the common good.

As statesmen, the Founders knew and rejoiced that they were not the first to try to strike that balance; they looked back to the English Commonwealth, even as the leaders of that Commonwealth looked back to the Roman Republic. As Patrick Henry put it, "Caesar had his Brutus; Charles I, his Cromwell; and George III . . . may profit from their example." ${ }^{18}$ As John Milton, functioning as Cromwell's foreign secretary, reminded the crowned heads after English judges had decapitated their king and abolished the monarchy, Rome had been a Republic before it became an empire; as the historian Edward Gibbon reminds us, the values of the Roman Republic were sometimes better preserved by its military emperors than by its civilian senators.

The best of those senators, like the best of those emperors, believed, with our Founders, that the best government is not that which governs least, but that in which the wise rule for the common good. Perhaps Marcus Aurelius-philosopher and ruler, emperor and general-put it best of all: 
As you are yourself a complement of a social system, so let every act of yours be complementary of a social living principle. Every act of yours, therefore, which is not referred, directly or remotely to the social end sunders your life, does not allow it to be a unity, and is a partisan act, like a man in a republic who for his own part sunders himself from the harmony of his fellows. ${ }^{79}$

May all of us, whether our service be civilian or military, profit from what he practiced as well as preached.

\section{ENDNOTES}

1. This monograph is part of a larger review of Samuel P. Huntington's study, The Hidden Promise of Huntington's The Soldier and the State: Military Professionals as Guardians of the Republic, available from the author of this SSI monograph upon request.

2. Eliot Freidson, Professionalism, The Third Logic: On the Practice of Knowledge, Chicago, IL: University of Chicago Press, 2001, p. 146.

3. For a succinct review of these positions on current issues, see Don Snider, Strategic Insights: Should General Dempsey Resign? Army Professionals and the Moral Space for Military Dissent, Carlisle, PA: Strategic Studies Institute, U.S. Army War College, October 21, 2014, available from www.strategicstudiesinstitute.army.mil/ index.cfm/articles/Should-General-Dempsey-Resign/2014/10/21.

4. Samuel P. Huntington, The Soldier and the State: The Theory and Politics of Civil-Military Relations, Cambridge, MA: Harvard University Press, 1957, p. 84.

5. Ibid., pp. 84-85.

6. Ibid., pp. 8-10, outlines the professional officer's "expertise" and "responsibility." 


\section{Ibid.}

9. Ibid., p. 70. See also Matthew Moten, "Root, Miles, and Carter: Political-Cultural Expertise and an Earlier Army Transformation," Lloyd J. Matthews, ed., The Future of the Army Profession, 2nd Ed., New York: McGraw-Hill Higher Education, April 2005, p. 738, "In an ideal world, military professionals would remain unequivocally subordinate to their civilian masters, who would, in turn, develop clear, unambiguous, and unchanging policy goals prior to a forthright declaration of war"; Marybeth Peterson Ulrich, "Infusing Civil-Military Relations Principles in the Officer Corps," Matthews, ed., The Future of the Army Profession, pp. 655, 659, "The ideal match-up occurs when civilian leaders have high competence and responsibility." (Emphasis in original.)

\section{Huntington, note 5, p. 71.}

11. Ibid. See also Suzanne C. Nielsen, "Rules of the Game? The Weinberger Doctrine and the American Use of Force," Matthews, ed., The Future of the Army Profession, note 10, pp. 627, 632640, showing that both Huntington and Janowitz essentially and properly adopt Clausewitz's view that "domestic political matters and the derivation of policy goals" are outside the province of military professionals.

12. Huntington, note 5, p. 76 .

13. Ibid., p. 77.

\section{Ibid.}

\section{Ibid.}

16. It is worth noting that the officers' oath is not to obey any particular civilian officer, but to uphold the Constitution and faithfully discharge the duties of the office:

I, __ (SSAN), having been appointed an officer in the (Military Branch) of the United States, as indicated above in the grade of do solemnly swear (or affirm) that I will support 
and defend the Constitution of the United States against all enemies, foreign or domestic, that I will bear true faith and allegiance to the same; that I take this obligation freely, without any mental reservations or purpose of evasion; and that I will well and faithfully discharge the duties of the office upon which I am about to enter; So help me God.

17. Eric Schmitt, "Threats and Responses: Military Spending; Pentagon Contradicts General on Iraq Occupation Force's Size," The New York Times, February 28, 2003, available from www. nytimes.com/2003/02/28/us/threats-responses-military-spendingpentagon-contradicts-general-iraq-occupation.html.

18. See Thom Shanker, "Retiring Army Chief of Staff Warns Against Arrogance," The New York Times, June 12, 2003, available from www.nytimes.com/2003/06/12/us/retiring-army-chief-ofstaff-warns-against-arrogance.html.

19. Try not to think of the current situation in Syria and Iraq.

20. Huntington, note 5, p. 122.

21. Except, perhaps, in the most extreme and self-limiting case, when resignation rather than implementing tactically unsound orders would result in a greater military catastrophe than implementing those orders.

22. Huntington, note 5, p. 76, nicely illustrates this complexity with the example of a junior officer's pressing for the introduction a new technique in the face of superiors' opposition:

[T] he subordinate must consider whether the introduction of the new technique, assuming he is successful in his struggle, will so increase military efficiency as to offset the impairment of that efficiency caused by the disruption of the chain of command.

23. See Carl Ceulemans and Guy van Damme, "The Soldier and the State: An Analysis of Samuel Huntington's View on Military Obedience Toward Political Authority," Professional Ethics, Vol. 10, pp. 7, 11: 
[Huntington's analysis] implies that if it could be proven in one way or another that the political analysis of the military officer were much sounder than that of the statesman, then the former would not only have the right to disobey, he probably would have an obligation to do so.

24. See Martin L. Cook, "Army Professionalism: Service to What Ends?" Matthews, ed., The Future of the Army Profession, 2nd Ed., note 10, pp. 683, 689, explicitly rejecting, on empirical grounds, the view that skill and wisdom about how to employ military forces reside not among military officers at all, but among those who use the military as obedient tools, employed in ways and for ends beyond the purview of military officers themselves. (footnote omitted).

\section{Huntington, note 5, p. 71.}

26. Ibid., p. 70, citing Field Marshal Earl Wavell, The Good Soldier, London, UK, 1948, pp. 27-28. This approving reference to politics as a profession, we must note, is in considerable tension with Huntington's rhetorical flourish elsewhere that "politics is an art, military science a profession." Ibid., p. 76. The latter seems to make modern statesmen less the parallel to his modern professionalized military and more like the pre-professional "geniuses" that he very carefully eschews. See ibid., p. 28 (faulting 18th century military scholars because they "substituted glorification of natural genius for a conception of professional officership."); Ibid., p. 30 "The accepted 18th-century theory of generalship centered about the concept of a natural genius," which implied that "military command was an art like music or sculpture which required inherent talent" and thus "could not be transmitted or learned."

27. Ibid., p. 70, citing Field Marshal Earl Wavell, The Good Soldier, London, UK, 1948, pp. 27-28.

28. Ibid.

29. Freidson, "The ideology of professionalism asserts knowledge that is ... [a] wedding of liberal education to specialized training...." 
30. If that. See James Burk, "Responsible Obedience by Military Professionals," Suzanne C. Nielsen and Don M. Snider, eds., American Civil-Military Relations: The Soldier and the State in a New Era, Baltimore, MD: Johns Hopkins University Press, 2009, pp. 149, 157 (comparing "military professionals, who are specialists in violence," with "elected officials, who are specialists in persuasion"). In classical political philosophy, of course, the skill of persuasion is a dangerous tool in the hands of those who do not both know and serve the public good. See generally Plato, "Gorgias," in The Dialogues of Plato, 14th Ed., Benjamin Jowett, trans., New York: Random House, 1937; Aristotle, Rhetoric, W. Rhys Roberts, trans., New York: Modern Library, 1954.

31. B. H. Liddell Hart, The German Generals Talk, New York: Quill, 1948, p. 44, quoting General Kurt Dittmar, who relied in part on conversations with General Franz Halder, head of the General Staff from 1938 until 1942. Huntington quotes part of this account. See Huntington, note 5, p. 115.

32. Huntington, note 5, p. 92. See also Ernst Nolte, Leila Vennewitz, trans., Three Faces of Fascism: Action Française, Italian Fascism, National Socialism, New York: Mentor, 1966.

33. Hart, note 31, p. 9.

34. See Cook, note 24, p. 689.

One thinks, for example, of the fairly scathing criticism of Iraqi Freedom currently being offered by Gen. Anthony Zinni, former head of U.S. Central Command, as a fruitful case for reflection on this point [i.e., the greater freedom of retired officers to criticize civilian leadership].

General Barry R. McCaffrey, Foreword to American CivilMilitary Relations, note 30, pp. xiii, xv.

[M]any of our senior flag officers who encountered the arrogance, disingenuous behavior, and misjudgments of Secretary of Defense Donald Rumsfeld during the initial years of Operation Iraqi Freedom were ill-prepared to respond effectively. 
35. However, see Risa A. Brooks, "Militaries and Political Activity in Democracies," American Civil-Military Relations, note 30, pp. 212, 237.

In The Soldier and the State, Huntington correctly recognized that there are severe downsides to allowing militaries to engage in political activity in that it compromises their professionalism and therefore technical competency, but his analysis missed critical dimensions of the issue,

particularly "the potential positive effects of political activity." Ibid., p. 216:

[I]f military officers and their leaders forgo political activity, it may mean that the United States sometimes pursues more risky and less well-conceived military actions abroad than had those officers engaged in a more forceful and explicit effort to shape public debate about the issues.

Ulrich, note 10, p. 659 , argues that, normatively as well as descriptively:

democratic civil-military relations are characterized by military professionals who tolerate ... poor policy-making outcomes in order to preserve the more fundamental, longterm interest of upholding the democratic character of the state;

Ibid., p. 662-663, following Peter Feaver in characterizing as shirking "various degrees of military noncompliance with the political leadership's desired policy preferences" without regard to the relative policy merits of the civilian and military positions, citing Peter Feaver, "Crisis as Shirking: An Agency Theory Explanation of the Souring of American Civilian-Military Relations," Armed Forces and Society, Vol. 24, 1998, p. 407.

36. Huntington, note 5, p. 71.

37. Ibid.

38. Ibid. 
39. Ibid., p. 72; see also Richard K. Betts, "Are Civil-Military Relations Still a Problem?" American Civil-Military Relations, note 30, pp. 11, 36, "Huntington himself was not as explicit as he might have been about where exactly the lines should be drawn."

40. Huntington, note 5, p. 73; see also James E. Baker, “LBJ's Ghost: A Contextual Approach to Targeting Decisions and the Commander in Chief," Chicago Journal of International Law, Vol. 4, 2003, pp. 407, 408, "In many contexts, there are good policy reasons to restrict the manner in which a target is attacked that go beyond limitations required by the LOAC [Law of Armed Conflict]"; accordingly "a process of target decision entails the exercise of policy discretion as well as legal judgment and military command."

\section{Hart, note 31.}

42. Huntington, note 5, p. 73; see also Betts, note 39 , p. 36, reasoning that, although:

one could make the case that for ideal integration of objectives, strategy, and operations, civilians and military should be equally conversant in each other's terms of reference and should participate equally at all stages, ... few would deny that there is some level of high politics at which soldiers should be silent, and some level of tactical specificity or micromanagement where civilians should keep hands off.

Christopher P. Gibson, "Enhancing National Security and Civilian Control of the Military: A Madisonian Approach," American Civil-Military Relations, note 30, pp. 238, 242, "Objective control was fundamentally flawed from the outset because it presumed that the military and political spheres could be distinguished in a comprehensive and meaningful way." Richard H. Kohn, "Building Trust: Civil-Military Behaviors for Effective National Security," American Civil-Military Relations, note 30, pp. 264, 265:

Huntington's 'objective civilian control' assumed clear boundaries between policy and strategy, on the one hand, and tactics, operations, training, and military administration, on the other, that were diminishing in the dawning era of nuclear weapons and limited war. 
McCaffrey, note 34, p. xv, noting that some military leaders have unfortunately lacked "an essential sense of history, the law, languages, and other cultures, and how our constitutional form of government really works"; Moten, note 10, p. 739, "Moreover, 'at the highest level the art of war turns into policy,' where officers and civilian leaders alike can and do often demonstrate competencies in each other's jurisdictions"; Suzanne C. Nielsen and Don M. Snider, "Conclusions," American Civil-Military Relations, supra note 30, pp. 290, 292, "The most significant shortcoming of Huntington's construct was its failure to recognize that a separation between political and military affairs is not possible - particularly at the highest levels of policymaking." Nadia Schadlow, Charles Barry, and Richard Lacquement, "A Return to the Army's Roots: Governance, Stabilization, and Reconstruction," The Future of the Army Profession, note 10, p. 251, "The cultural challenge for the Army now is to re-embrace vigorously critical stability operations, particularly those associated with governance, economic stabilization, and reconstruction, as integral, inevitable parts of war itself." Leonard Wong and Don M. Snider, "Strategic Leadership of the Army Profession," The Future of the Army Profession, note 10, pp. 601, 603:

As the strategic leaders of a profession look outside their profession, they seek at higher levels of analysis to understand comprehensive trends, those macro influences of technology, politics, organization ... and even enemy adaptations, etc., which could cause jurisdictional changes for the Army.

Ibid., p. 617:

They [the Army's strategic leadership] understand the entire spectrum of operations at the strategic level to include theatre strategy; joint, interagency, and multinational operations; and the use of all the elements of national power and technology in the execution of national security strategy.

43. Huntington, note 5, p. 73; see also Richard Lacquement, "Mapping Army Professional Expertise and Clarifying Jurisdictions of Practice," The Future of the Army Profession, note 10, pp. 213,217 , listing "Political-Cultural" as an essential area of military professional knowledge, citing Huntington. (Emphasis added.) 
44. Huntington, note 5, p. 72.

45. Ibid.

46. Ibid.; see also Nielsen, note 12, p. 638, noting that Huntington's "representative" role for officers entails relative capabilities of both their own nation and its enemies and concluding that "[o]nce factors such as these are taken into account, it is doubtful that an assessment of military security needs could be based on purely military expertise."

47. See Mathew Moten, "A Broken Dialogue: Rumsfeld, Shinseki, and Civil-Military Tension," American Civil-Military Relations, note 30, pp. 42, 69, "The essential flaw in Huntington's theoretical wall is that it splits the responsibility for policy from the responsibility for strategy"; Williamson Murray, "Professionalism and Professional Military Education in the Twenty-First Century," American Civil-Military Relations, note 30, pp. 134, 135, "Officers who know only the tactical and operational framework of conventional military forces might offer faulty advice and then prove incapable of adapting to the real conditions of the conflict they have been asked to fight"; Ibid., p. 146, "[In the post-Cold War world,] the use of military power will demand cultural, historical, linguistic, and political knowledge as well as tactical and operational competence"; Nadia Schadlow and Richard A. Lacquement, Jr., "Winning Wars, Not Just Battles: Expanding the Military Profession to Incorporate Stability Operations," American Civil-Military Relations, note 30, pp. 113-114, "Huntington's reliance on an abstract construct that removes political judgment from the realm of military professionalism unduly narrows the focus of military leaders to operations and tactics"; Don M. Snider, "The U.S. Army as a Profession," in The Future of the Army Profession, note 10, pp. 1, 53, "To a greater extent than when fighting war, the management of defense and peace requires the military professional to cooperate and compete with other professions as it goes about its work."

48. Eric Schmitt, "Threats and Responses: Military Spending; Pentagon Contradicts General on Iraq Occupation Force's Size," The New York Times, February 28, 2003, available from www. nytimes.com/2003/02/28/us/threats-responses-military-spendingpentagon-contradicts-general-iraq-occupation.html. 
49. Huntington, note 5, p. 73.

50. Immanuel Kant, Lewis White Black, trans., Foundations of the Metaphysics of Morals, New York: Macmillan Publishing Company, 1989, pp. 31-32.

51. See Wong and Snider, note 42, pp. 611-612, "For example, strategic leaders need to be politically savvy - knowing when to compromise, knowing that many strategic decisions are not black and white, and knowing what is best in the long run for the nation and the army." See also Ceulemans and van Damme, note 23, p. 11, "[I]t seems rather strong [of Huntington] to deny the fact that people in a society could share some basic principles of common good, and consequently, that political decisions could be judged based on these commonly shared values."

52. See John Mark Mattox, "The Moral Foundations of Army Officership," The Future of the Army Profession, note 10, p. 396:

Likewise, it has long been understood that, inasmuch as Army officers are entrusted by the state with the power to preserve or threaten lives, they must be individuals of character who are committed to the properly constrained use of that power, both in its legal and moral dimensions.

We can separate law from morality for analytic purposes without conceding that they need be separated permanently, nor whether that separation is, in any ultimate sense, possible. Later analysis reunites the two, insisting that military officers, like all professionals, must make the moral assessment, whether they make it inside the law, or out.

53. See Burk, note 30, p. 159, "In an effort that is difficult to reconcile with his earlier assertions about the supreme virtue of instant and unthinking obedience, Huntington tries to define the limits of obedience." (citation omitted.)

54. Huntington, note 5, p. 77.

55. Ibid., pp. 77-78.

56. Ibid., p. 78. 
58. See Peter Margulies, Law's Detour: Justice Displaced in the Bush Administration, New York: New York University Press, 2010, p. 60; David Luban, Legal Ethics and Human Dignity, Cambridge, UK: Cambridge University Press, 2007, "Yoo justified his advice with analogies that defied common sense."

59. See Huntington, Part II.B.2.

60. This is, we might note, a very old objection indeed. See Aristotle, note 30, p. 88:

We must say that evidence under torture is not trustworthy, the fact being that many men whether thick-witted, toughskinned, or stout of heart endure their ideal nobly, while cowards and timid men are full of boldness till they see the ordeal of these others: so that no trust can be placed in evidence under torture.

61. Perhaps the most egregious lapse of legal reasoning was to overlook a distinction familiar to every layperson: Even a dog knows the difference between tripped over and being kicked. The torture memo, overlooking this distinction, tries to shed light on a statute about the amount of pain government officials may intentionally inflict from a statute that addresses government obligation to redress pain that the government has not caused. Just to be clear: I say "overlooked" here in the name of charity, not unmindful of the difference between inadvertent and intentional wrongs. See Margulies, note 56, p. 60, "Yoo justified his advice with analogies that defied common sense."

62. See James E. Baker, "Process, Practice, and Principle: Teaching National Security Law and the Knowledge that Matters Most," Georgetown Journal of Legal Ethics, Vol. 27, No. 163, 2014, p. 171, "They [policy-makers] are impressed with the lawyer who relates law to fact connecting the humane treatment of prisoners to better intelligence. . . ."; James E. Baker, "What's International Law Got to Do with It? Transnational Law and the Intelligence Mission," Michigan Journal of International Law, Vol. 28, No. 639, 2007, pp. 655-656, anecdotal evidence from Russian occupation of Afghanistan that humane treatment of prisoners enhances intelligence gathering. 
63. See Luban, note 56, p. 167, "With the worldwide adoption of CAT [Convention Against Torture], torture became an international crime."

64. Huntington, note 5, p. 78.

65. Malcolm N. Shaw, International Law, Vol. 455, 6th Ed., 2008:

The effective control of a new government over the territory of the state is thus an important guideline to the problem of whether to extend recognition or not, providing such control appears well established and likely to continue.

66. This is not the place to answer worries that the Nuremberg verdicts were unfair either as a form of "victors' justice" or as retroactive. Still, a bit about both points. On the first, even if we must concede, with the citizens of Melos to the Athenian fleet, that the powerful can make the law whatever they will, we can nonetheless observe, as the Melians also did, that the powerful have a basic choice. They can make the law serve their own narrow interest, or they can make the law serve the interests of all, the common good. On the second, it would be a bit hard for the Nazis to deny that they were on notice about prevailing humanitarian norms when they had made an ideology of attacking and displacing those very norms.

67. Huntington, note 5, p. 78.

68. Ibid.

69. Aristotle, note 30, p. 216, "Gorgias said that you should kill your opponent's earnestness with jesting and their jesting with earnestness; in which he was right." It is worth remembering that Aristotle could not have forgotten what his own teacher had taught him: Gorgias was not a philosopher, but an infamous sophist. See Plato, note 30.

70. Huntington, note 5, p. 78.

71. Ibid.

72. Ibid. 
73. Ibid.

74. See Burk, note 30, p. 162, "Huntington too quickly dismisses moral reasoning and finds no place for moral responsibility within the military professional's role."

75. Cook, note 24, p. 689.

76. See Burk, note 30, p. 161, "A decision to begin genocide is impossible to justify under any [acceptable] moral paradigm, and so it cannot constitute a lawful order."

77. See Mattox, note 50, p. 397,

They [army officers] are moral agents who must recognize their responsibility (1) never to issue an immoral order, and (2) to refuse an order-even a suggestion-to undertake military operations inconsistent with the ideals they are sworn to defend.

78. Patrick Henry, Speech on the Stamp Act, Virginia House of Burgesses, May 29, 1765.

79. Marcus Aurelius, Meditations, Vol 60, 9th Ed., A. S. L. Farquharson, trans., New York: Everyman's Library, 1961. 


\title{
U.S. ARMY WAR COLLEGE
}

\author{
Major General William E. Rapp \\ Commandant
}

\section{***** \\ STRATEGIC STUDIES INSTITUTE and U.S. ARMY WAR COLLEGE PRESS}

\author{
Director \\ Professor Douglas C. Lovelace, Jr.
}

Director of Research

Dr. Steven K. Metz

\author{
Author \\ Mr. Robert E. Atkinson, Jr. \\ Editor for Production \\ Dr. James G. Pierce \\ Publications Assistant \\ Ms. Rita A. Rummel \\ ***** \\ Composition \\ Mrs. Jennifer E. Nevil
}




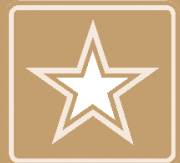

U.S.ARMY

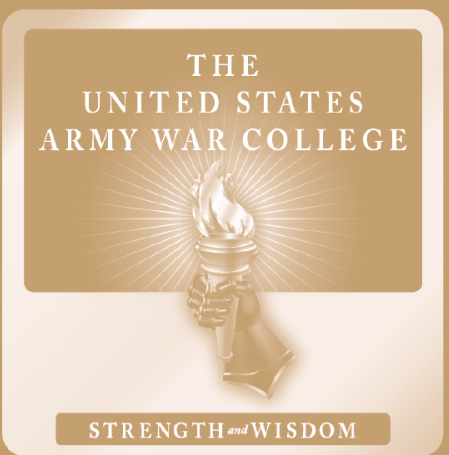

FOR THIS AND OTHER PUBLICATIONS, VISIT US AT http://www.carlisle.army.mil/

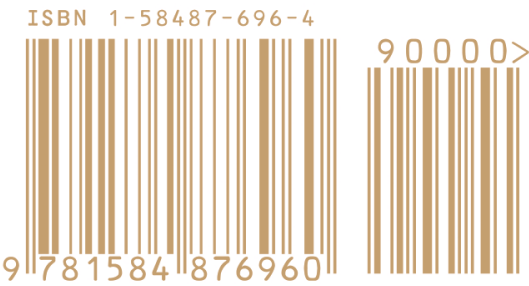

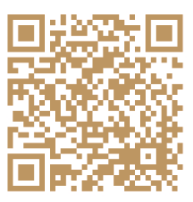

This Publication
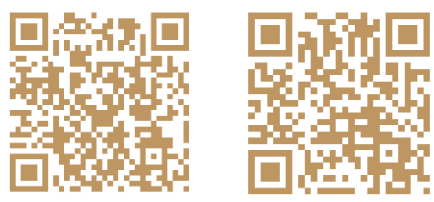

SSI Wensite
USAWC Wehsite 